\title{
Student Design Teams at UWO: a Case Study
}

\author{
Ralph Buchal, Director of Integrated Engineering and Design Education \\ Imran Atcha, Western Sunstang Solar Car Project Manager \\ Alberto Da Rocha, Western Formula SAE Team Manager \\ Robert Jelenic, Western Mini Baja Team Manager \\ Peter Kriznic, Western SAE Aero Design Team Leader
}

\author{
Faculty of Engineering \\ The University of Western Ontario \\ London, Ontario \\ rbuchal@eng.uwo.ca
}

\begin{abstract}
Major student design competitions like Formula SAE, Mini Baja and American Solar Challenge provide a valuable learning experience. These competitions develop skills and experience in many important areas, some of which are not well developed in the formal curriculum. This paper examines several teams at the University of Western Ontario including: Formula SAE, Mini Baja, SAE Aero, and Sunstang solar car. The focus is on common elements including team structure and management, budgets and resources, design processes, use of $C A D / C A M / C A E$ tools, design communication, and prototype testing.
\end{abstract}

\section{Introduction and background}

After years of neglect, design experience, practical knowledge and soft skills have again become important objectives of engineering education. These skills are demanded by industry $[1,2]$, and have been incorporated into ABET [3] and CEAB [4] accreditation criteria. Recently, the Canadian Design Engineering Network (CDEN) was formed "to promote the development and sharing of educational engineering tools among all Engineering Schools within Canadian Universities" [5]. The need has also been recognized by the Natural Sciences and Engineering Research Council of Canada (NSERC), which has established the Chairs in Design Engineering Program to "improve the level and quality of design engineering activity within Canadian universities" [6].

Large, multi-year student design projects have been incorporated into the undergraduate curriculum at some engineering schools. For example, such projects have been part of the Carleton University curriculum for over a decade [7]. These large projects are run as "virtual enterprises", and provide a very rich design experience. However, such projects require a heavy faculty workload and many engineering schools are unable to commit the required resources.

The major student design competitions like Formula SAE, Mini Baja and American Solar Challenge are also large, multi-year design projects. Virtually every engineering school has these teams, which are mostly extracurricular and student-run. These projects provide many of the educational benefits of faculty-run projects, but with a fraction of the faculty workload.

This paper compares and contrasts several student teams at the University of Western Ontario. Several aspects are examined, and related to important learning objectives and skills.

\section{The Teams}

This paper examines four established student design teams at the University of Western Ontario. 


\section{Sunstang Solar Car}

The Sunstang team designs and builds a solar car to compete in international competitions including the American Solar Challenge [8], Formula Sun Grand Prix [9], and World Solar Challenge [10]. The team has existed since 1991 , and was $12^{\text {th }}$ overall and the $2^{\text {nd }}$ North American team in the 1996 World Solar Challenge.

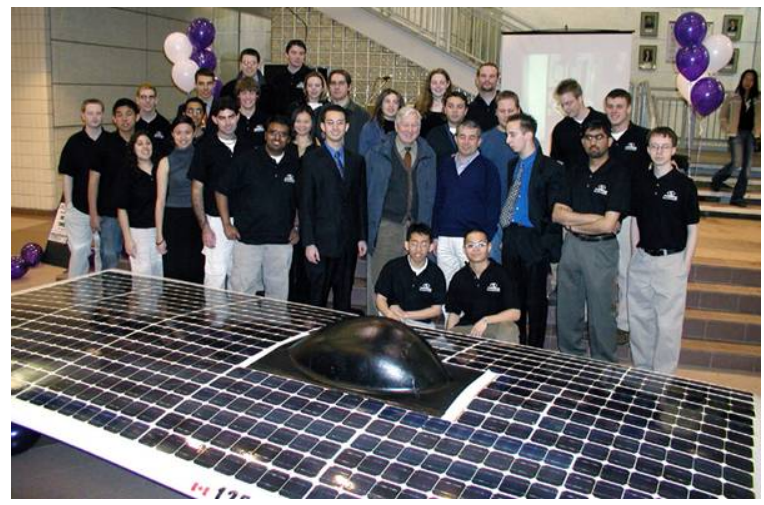

Figure 1. Sunstang Solar Car Team

\section{Formula SAE [11]}

The Formula SAE team competes against over 100 schools from around the world at the annual Formula SAE competition in Pontiac, Michigan. The team has competed annually since 1996 . Their best placing to date was $8^{\text {th }}$ overall in 2002 .

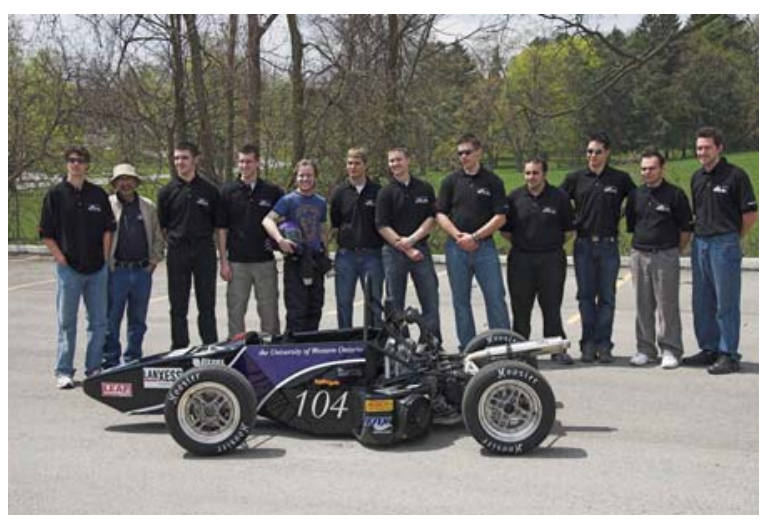

Figure 2. Formula SAE Team

\section{SAE Mini Baja [12]}

The Western Mini Baja team competes in the annual SAE Mini Baja competition. The team was established in 1997 , and placed $18^{\text {th }}$ overall in the $2000 \mathrm{SAE}$ Midwest Mini Baja competition.

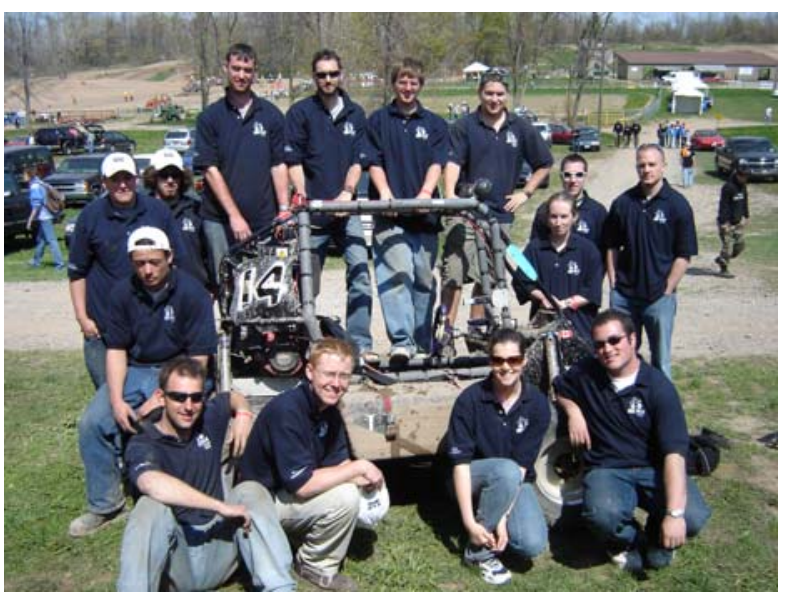

Figure 3. SAE Mini Baja Team

\section{SAE Aero Design [13]}

The Western SAE Aero Design team started in 1999. Their goal is to design and build a radio-controlled cargo plane. This is the youngest and smallest of the Western design teams.

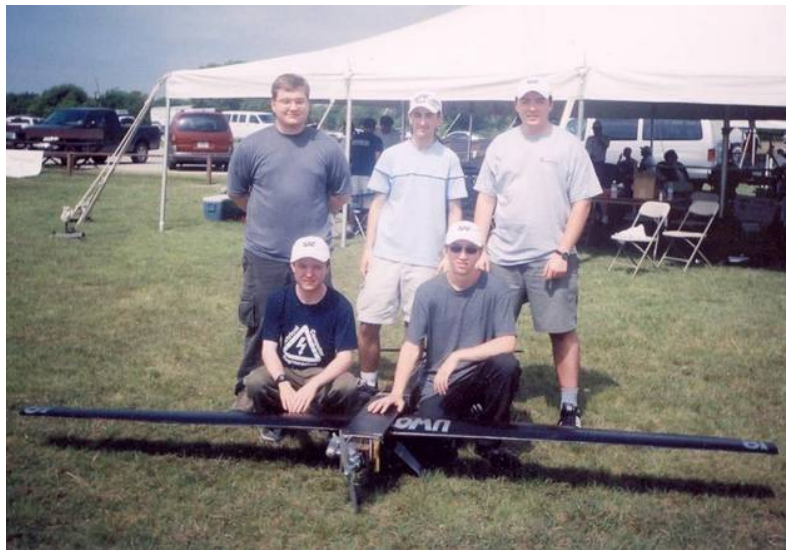

Figure 4. SAE Aero Design Team

\section{Team Size and Composition}

The teams are diverse and interdisciplinary, reflecting industry practice. Figure 5 shows the distribution of disciplines among the teams. 


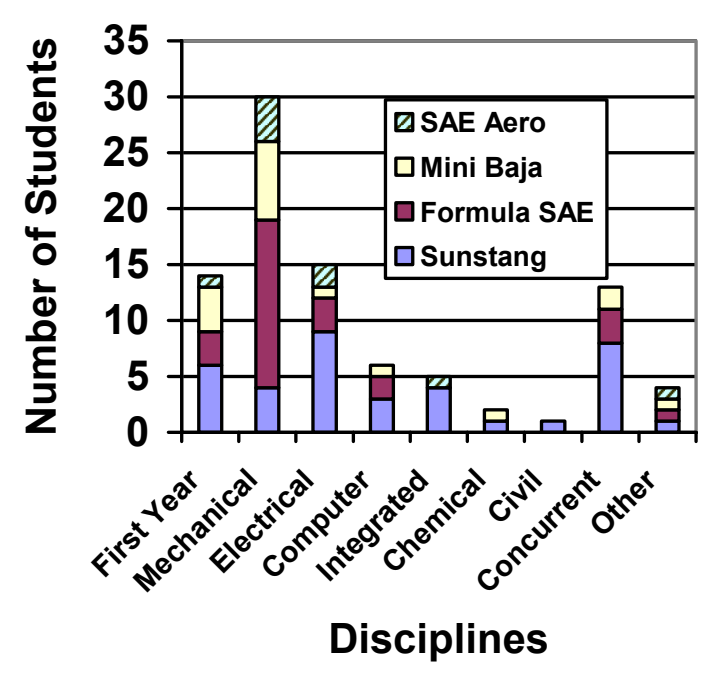

Figure 5. Distribution of disciplines

Many students participate on the team for more than one year, and start in first or second year. Each team has a mix of experienced and new members. Figure 6 shows the distribution of students by graduating year, and Figure 7 shows the distribution of years of experience on the team.

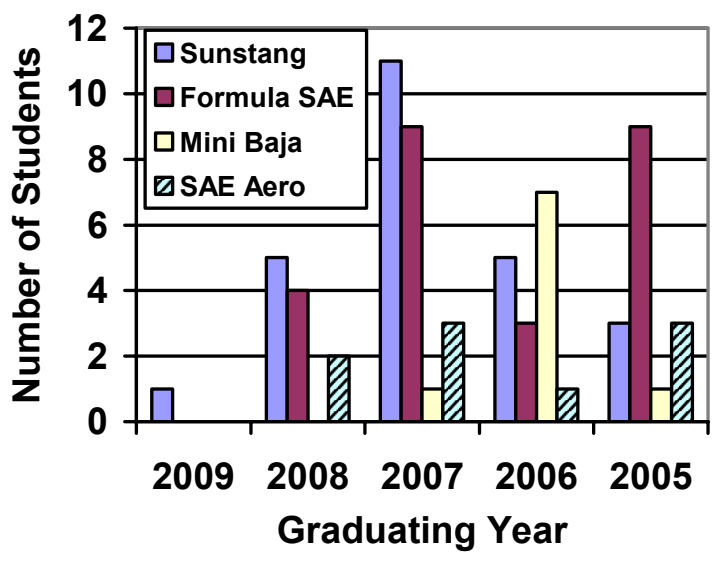

Figure 6. Distribution of students by graduating year

Only a minority of the members of each team are in their final year. All teams have many lower year students. For three of the teams, the largest group of members is in second year. In 2004/05, the majority of the members of the Mini Baja team were in third year.

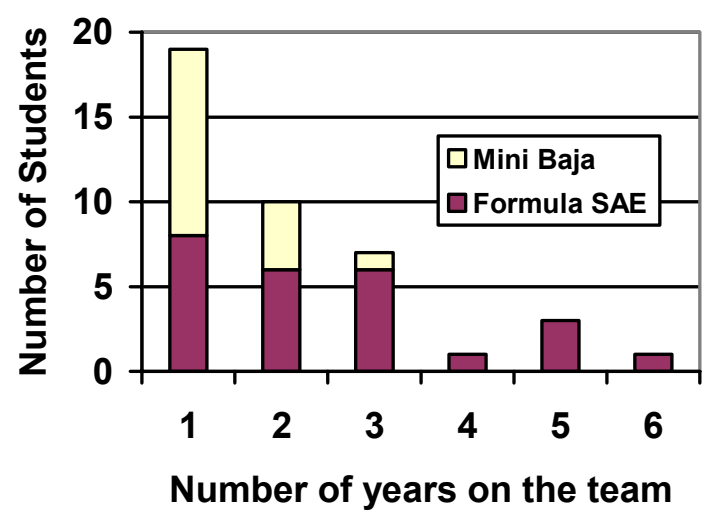

Figure 7. Distribution of students by years on the team

In addition to undergraduate students, the teams are assisted by alumni advisors. For example, Sunstang has three active alumni advisors who graduated in 1996 and 1997.

\section{Team organization and project management}

Each team has a well-defined management structure. The teams are all managed by students, with faculty members serving in an advisory capacity. On most teams, the faculty advisor does not appear on the organizational structure. All team managers are students.

Figure 8 shows the organizational structure of the Sunstang team. The other teams have similar organizational structures. 
Project Manager

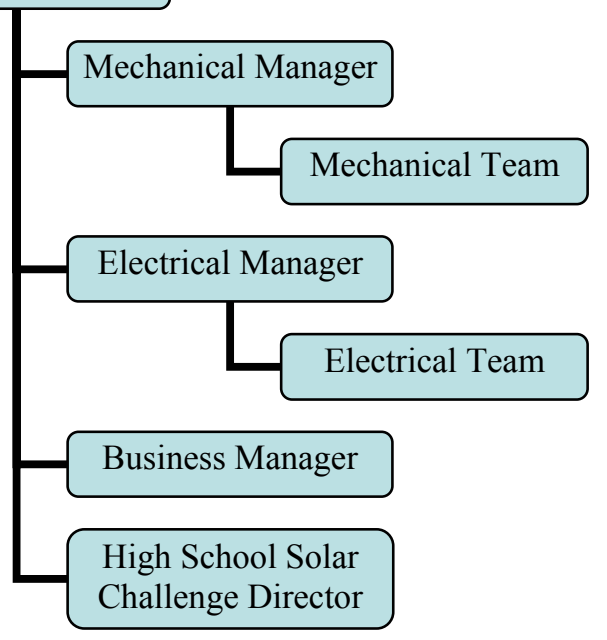

Figure 8. Sunstang organizational structure

The teams operate under strict timelines, and have limited budgets and resources. They establish schedules and milestones, assign tasks, and allocate resources. Great effort is typically required as the competition date approaches, but Western teams rarely miss a competition.

\section{Budgets and resources}

The annual budget for the design teams is quite significant, and varies with team size and maturity. The Western teams are largely self-funded, and rely on fundraising and corporate sponsors. Limited resources are made available by the University as well.

Table 1. Team information

\begin{tabular}{|l|l|l|l|}
\hline Team & Founded & $\begin{array}{l}\mathbf{2 0 0 4} / \mathbf{0 5} \\
\text { Team } \\
\text { Size }\end{array}$ & $\begin{array}{l}\text { Annual } \\
\text { budget }\end{array}$ \\
\hline Sunstang & 1991 & 26 & $\begin{array}{l}\$ 150 \mathrm{~K}- \\
\$ 200 \mathrm{~K}\end{array}$ \\
\hline $\begin{array}{l}\text { Formula } \\
\text { SAE }\end{array}$ & 1995 & 25 & $\$ 30 \mathrm{~K}-\$ 50 \mathrm{~K}$ \\
\hline $\begin{array}{l}\text { SAE Mini } \\
\text { Baja }\end{array}$ & 1997 & 20 & $\$ 10 \mathrm{~K}-\$ 15 \mathrm{~K}$ \\
\hline $\begin{array}{l}\text { SAE Aero } \\
\text { Design }\end{array}$ & 1999 & 9 & $\$ 5 \mathrm{~K}-\$ 10 \mathrm{~K}$ \\
\hline
\end{tabular}

They have access to computers and limited workshop space. Routine construction is completed by the students, giving valuable hands-on experience. Complex fabrication like $\mathrm{CNC}$ machining is outsourced, providing students a realistic experience in dealing with technicians and skilled trades. Expert machining and fabrication support is available on campus through University Machining Service, on a cost recovery basis.

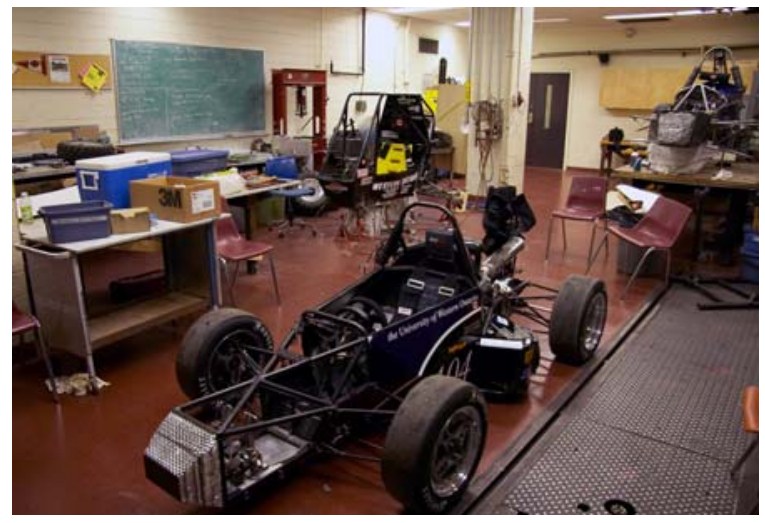

Figure 9. Work area for Formula SAE and Mini Baja teams

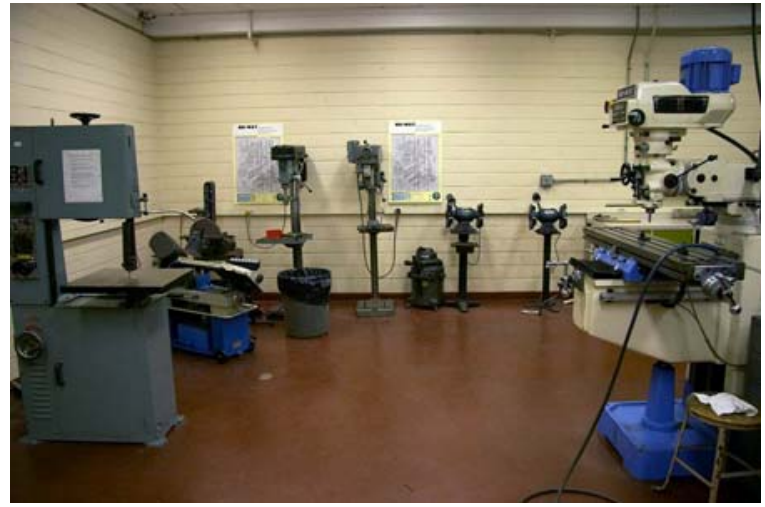

Figure 10. Student workshop

\section{Attitudes, commitment and morale}

The projects are largely extra-curricular. Despite lack of academic credit, student commitment to the projects is very high. Students typically spend breaks and summers working on these projects, and most delay starting work after graduation in order to work on the project and participate in the competition. 


\section{Mentorship, leadership and apprenticeship}

The teams have evolved informal apprenticeship systems, where senior members mentor new members. Students naturally progress to leadership positions over time. The team leaders typically have several years of experience, as shown in Table 2.

Table 2. Years of experience of team leaders

\begin{tabular}{|l|l|}
\hline Team & $\begin{array}{l}\text { Years of experience } \\
\text { of team leader }\end{array}$ \\
\hline Sunstang & 3 \\
\hline Formula SAE & 6 \\
\hline SAE Mini Baja & 3 \\
\hline SAE Aero Design & 2 \\
\hline
\end{tabular}

Since these teams are student managed, the team leader's job is very difficult and challenging. The teams typically share leadership responsibility among several of the most experienced team members.

\section{Design processes and methodologies}

The design teams apply the modern design processes taught in the undergraduate curriculum. Sometimes a new team will construct something "by the seat of their pants", but they quickly learn the importance of a sound design process when the prototype performs poorly.

The teams follow a design-build-test cycle as shown in Table 3.

Table 3. Typical design cycle

\begin{tabular}{|l|l|}
\hline Design Activity & Schedule \\
\hline $\begin{array}{l}\text { Design, analysis and } \\
\text { engineering }\end{array}$ & Summer, or previous year \\
\hline $\begin{array}{l}\text { Fabrication and redesign, } \\
\text { component and subsystem } \\
\text { testing }\end{array}$ & $\begin{array}{l}\text { During school year, } \\
\text { mostly second term and } \\
\text { after final exams }\end{array}$ \\
\hline Final testing & Usually 1-2 weeks before \\
\hline
\end{tabular}

\begin{tabular}{|l|l|}
\hline & competition. \\
\hline Competition & May - June \\
\hline
\end{tabular}

\section{Design innovation}

The teams constantly seek and incorporate innovations to improve their designs relative to the previous iteration, and relative to the competing teams. Often these innovations have a two or three year development cycle before they are incorporated into the prototype. For example, the Formula SAE has been developing and testing an innovative semi-active suspension system for the past two years.

Examples of key innovations are shown in Table 4.

Table 4. Selected Design Innovations.

\begin{tabular}{|l|l|}
\hline Team & $\begin{array}{l}\text { Innovations and } \\
\text { improvements }\end{array}$ \\
\hline Sunstang & $\begin{array}{l}\text { Composite aerobody and chassis } \\
\text { Lithium Ion Polymer batteries, } \\
\text { with protection and monitoring } \\
\text { system } \\
\text { In-hub motors } \\
\text { Advanced power management } \\
\text { system }\end{array}$ \\
\hline Formula SAE & $\begin{array}{l}\text { Semi-active suspension } \\
\text { Variable-geometry exhaust }\end{array}$ \\
\hline SAE Mini Baja & $\begin{array}{l}\text { Reduced weight } \\
\text { Improved reliability } \\
\text { Incremental improvements }\end{array}$ \\
\hline SAE Aero Design & $\begin{array}{l}\text { Lifting Canard } \\
\text { Forward facing engine in pusher } \\
\text { configuration } \\
\text { Hybrid winglet/rudder }\end{array}$ \\
\hline
\end{tabular}




\section{Use of CAD/CAM/CAE}

When teams first start up, the original members are often a group of tinkerers who cobble together a prototype "on the fly", with little up-front design. While these prototypes often work, they are typically overweight, underperforming, and failure prone. As the teams evolve through several design iterations, they learn the importance of following a design process. They quickly reach a stage of development where components and assemblies are completely modeled and analysed using modern $\mathrm{CAD} / \mathrm{CAM} / \mathrm{CAE}$ tools. Working drawings and $\mathrm{CNC}$ machining programs are generated directly from the CAD models.

Several leading CAD/CAM/CAE packages are used by Western teams, including:

- Solid Edge

- SolidWorks/COSMOSWorks

- Unigraphics

- IDEAS

- Pro/Engineer

Figure 11, Figure 12 and Figure 13 show CAD models of the Formula SAE car, the Mini Baja vehicle, and the Sunstang solar car, respectively.

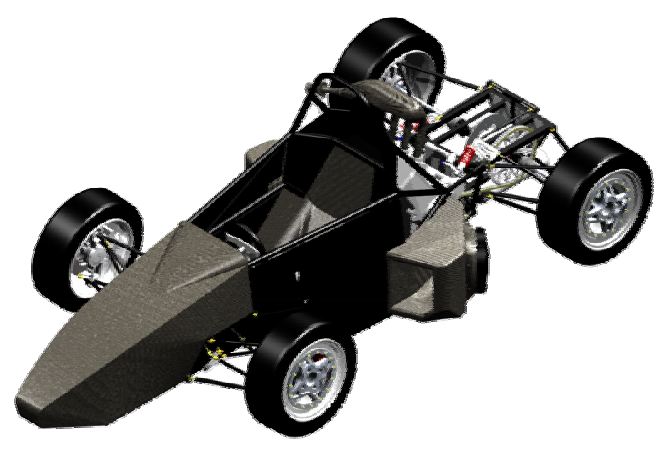

Figure 11. SolidWorks CAD model of 2005 Formula SAE car

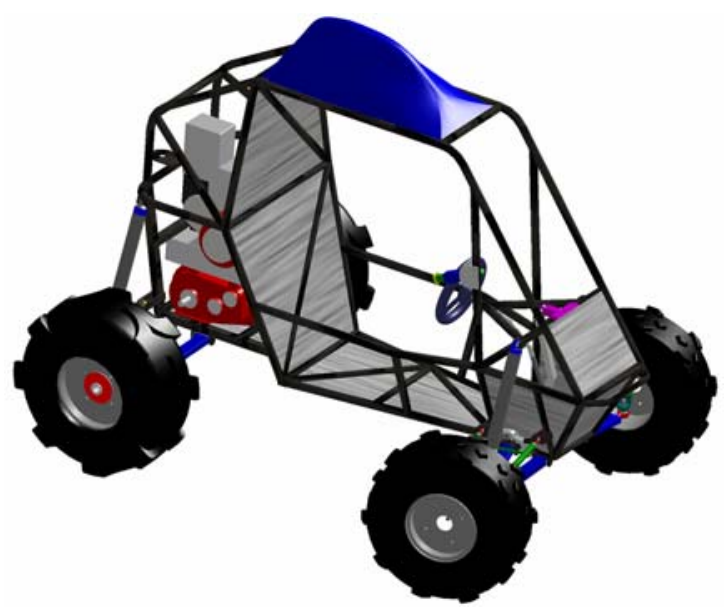

Figure 12. SolidWorks CAD model of SAE Mini Baja vehicle

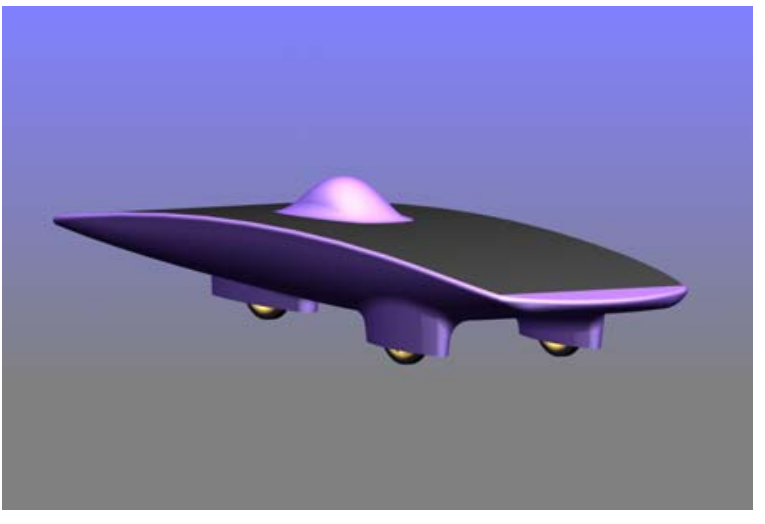

Figure 13. Unigraphics CAD model of Sunstang solar car

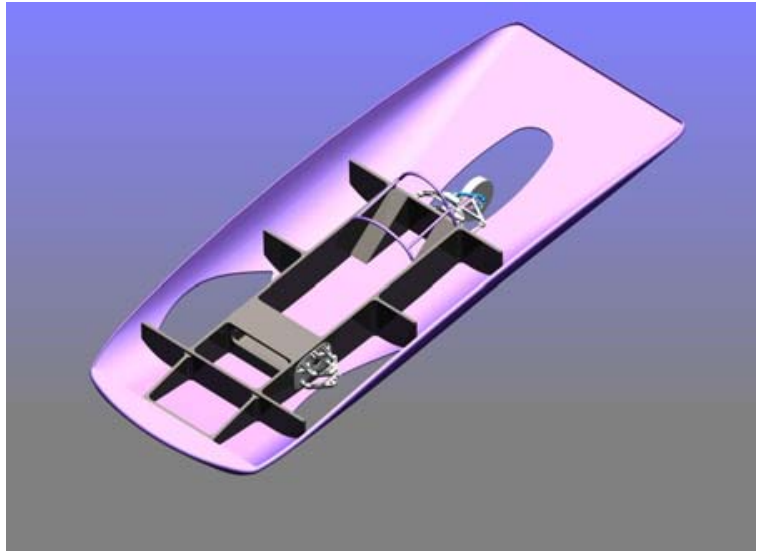

Figure 14. Chassis model of Sunstang solar car 
The following figures show examples of CAE analysis applied to components of the Formula SAE car. Figure 15 shows the results of a CFD study on the exhaust system, and Figure 17 shows FEA results for the front wheel spindle shown in Figure 16.

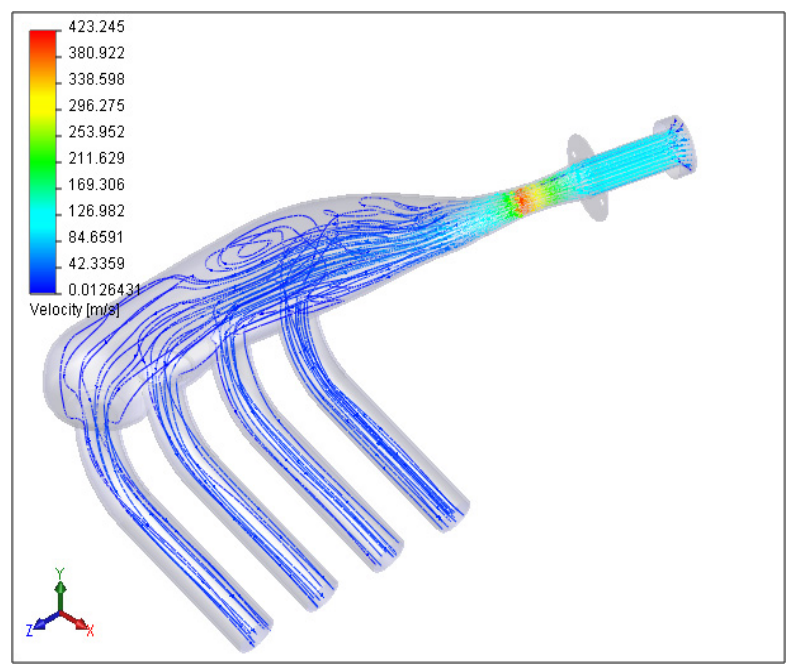

Figure 15. COSMOS FloWorks CFD analysis of Formula SAE intake system

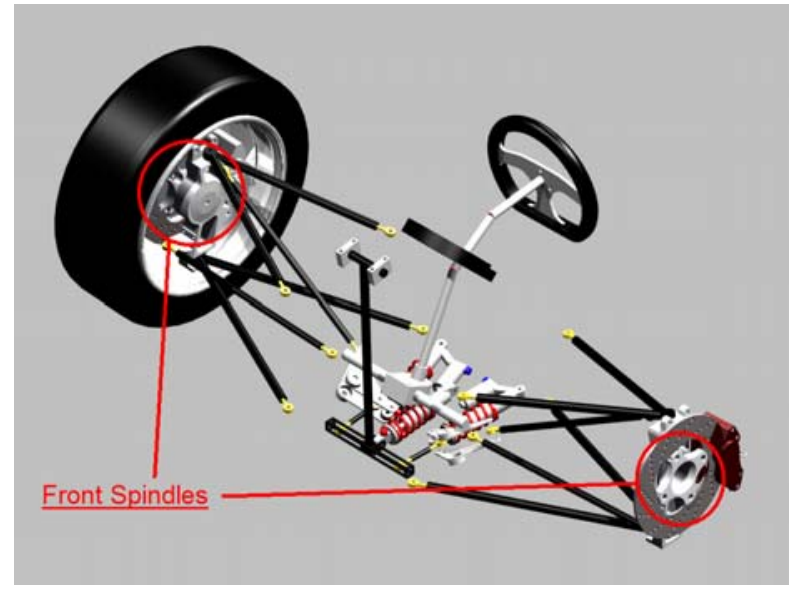

Figure 16. Location of front spindles on Formula SAE car

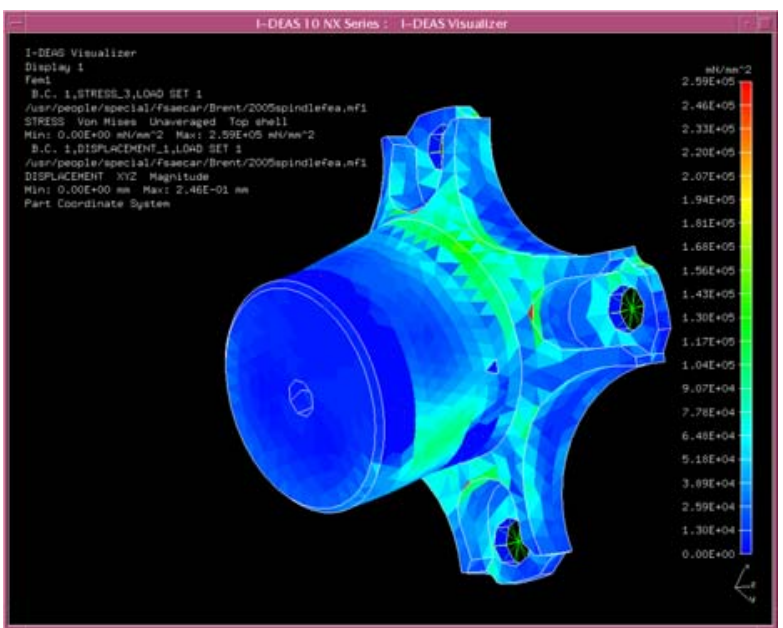

Figure 17. IDEAS FEA analysis of front spindle

\section{Prototype construction and testing}

Unlike most course-based design projects, the design teams construct and test high-quality, full scale functional prototypes. The final testing is the competition itself, where the prototype is objectively evaluated relative to a large number of competing designs. Performance criteria that are measured typically include: acceleration, braking, cornering, endurance, etc.

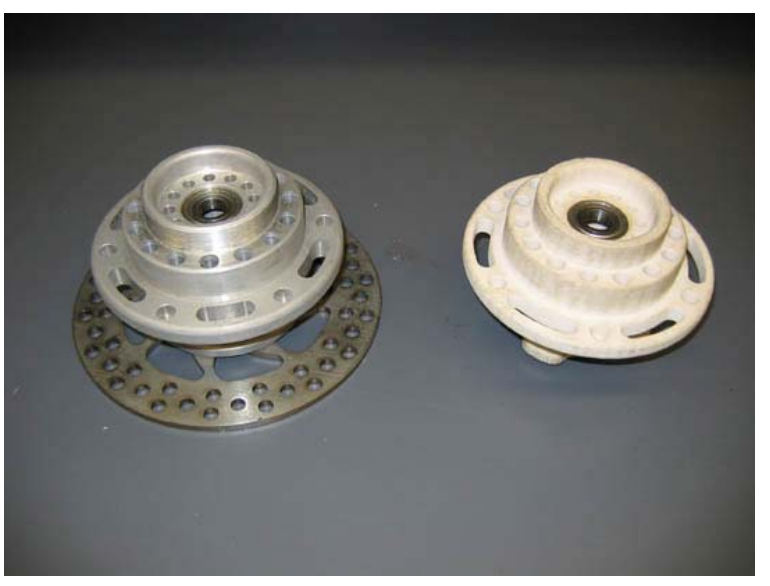

Figure 18. Sunstang hub assembly rapid prototype and finished part 


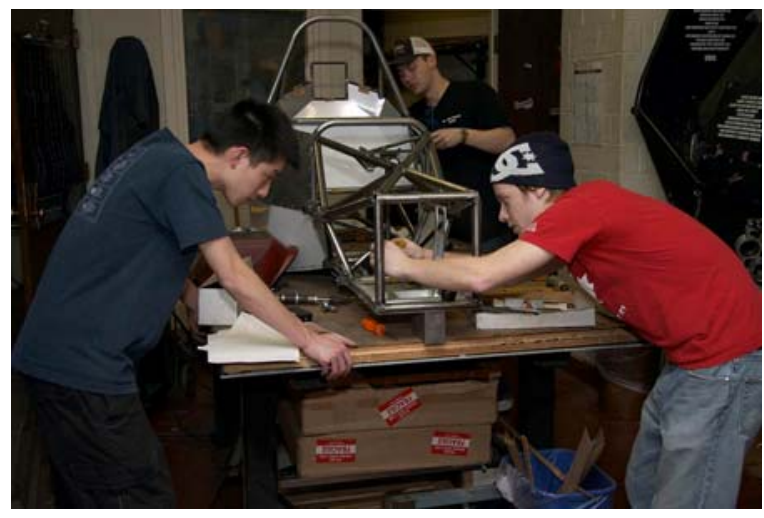

Figure 19. Students working on Formula SAE car

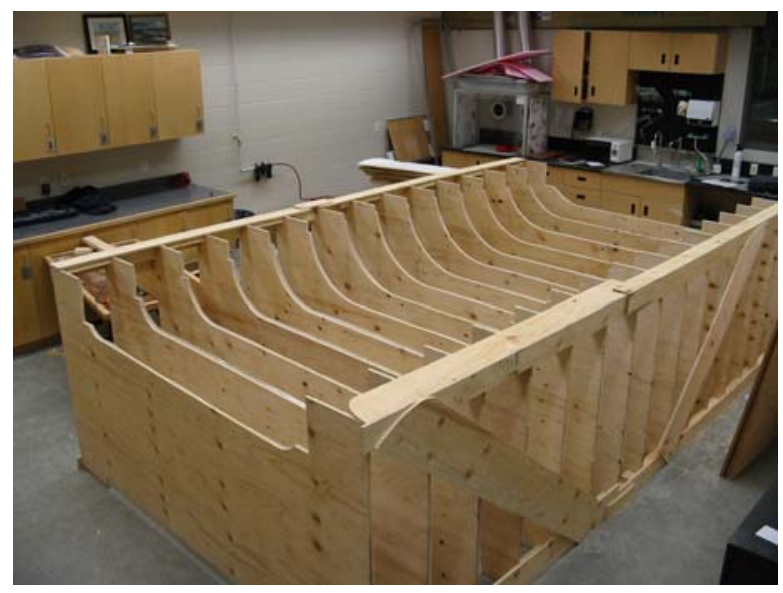

Figure 20. Wooden mold for Sunstang aerobody

For example, the Formula SAE team conducts extensive dynamometer testing of their engine to optimize various design parameters. Figure 22 shows a typical dynamometer test result.

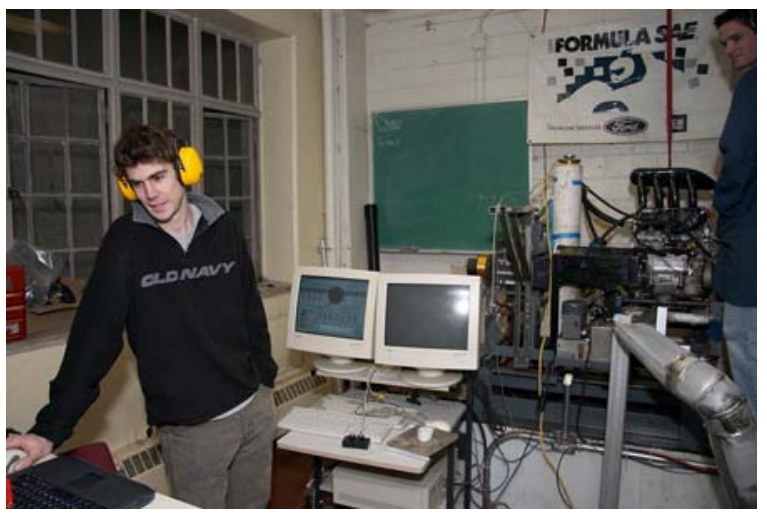

Figure 21. Formula SAE engine dyno testing

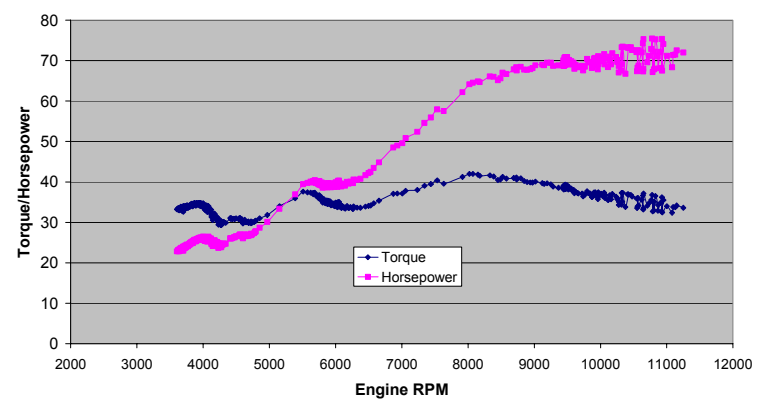

Figure 22. Dynamometer test data for Formula SAE engine

Students learn much more when encountering unforeseen circumstances and failures than when everything goes smoothly. Innovation and creativity is never required more than when students are forced to perform major repairs on the side of the track, under extreme time pressure and with limited tools and resources. Every year the importance of testing is driven home as some component or another fails during the competition.

\section{Design communication}

The teams develop strong communication skills through regular presentations and outreach activities. In addition, most of the competitions require the submission of a complete design report. In particular, the SAE student competitions have very thorough documentation and communication requirements. These include:

- A design report

- Engineering drawings 
- Detailed cost and manufacturing report

- Technical specification sheet

- Oral presentation

- Display boards and brochures

\section{Design iteration, reflection and learning from experience.}

The teams redesign their vehicles every year or two. Many team members participate for several years, so there is a transfer of knowledge and students learn from previous mistakes. Each design is an improvement over the previous version.

By participating for more than one year, most students experience more than one major design iteration. Design shortcomings are driven home forcefully at the annual competition and students are highly motivated to learn from their experience to improve the next design.

\section{Conclusions}

Student design competitions can provide an outstanding design experience, and can develop many of the skills sought by industry. The Western experience documented in this paper suggests that these projects can be student-managed, and that in fact this may be preferable to faculty-managed projects. As a result, incorporating this experience into the design education curriculum need not require a significant increase in faculty workload.

\section{References}

[1] Manufacturing Education Plan: 1999 Critical Competency Gaps, Society of Manufacturing Engineers, Dearborn MI, 1999, accessed at www.sme.org/foundation/reportphase1_update.pdf

[2] Engineers for Business Excellence: Study among Canadian Auto Industry Engineering Managers, The Strategic Council, July 2002

[3] Criteria for Accrediting Engineering Programs, Effective for Evaluation of Programs During the 2003-2004 Accreditation Cycle,
Accreditation Board for Engineering and Technology (ABET), Baltimore, MD, 2002.

[4] Accreditation Criteria and Procedures, Canadian Engineering Accreditation Board, Canadian Council of Professional Engineers, 2002.

[5] Canadian Design Engineering Network, www.cden.ca, visited May 13, 2005.

[6] Chairs in Design Engineering (CDE), Natural Sciences and Engineering Research Council of Canada, www.nserc.ca, visited May 13, 2005.

[7] AERO 4907/MECH 4907 design project descriptions, Department of Mechanical and Aerospace Engineering, Carleton University, http://www.mae.carleton.ca/maehtmls/projectscurrent.html, visited May 16, 2005.

[8] American Solar Challenge, http://www.americansolarchallenge.org/, visited May 19, 2005.

[9] Formula Sun Grand Prix, http://www.formulasun.org/fsgp/, visited May 19, 2005.

[10] World Solar Challenge, http://www.wsc.org.au/, visited May 19, 2005.

[11] Formula SAE Student Competition, Society of Automotive Engineers, http://students.sae.org/competitions/formulaseries/ , visited May 19, 2005.

[12] SAE Mini Baja Student Competition, Society of Automotive Engineers, http://students.sae.org/competitions/minibaja/, visited May 19, 2005.

[13] SAE Aero Design Student Competition, Society of Automotive Engineers, http://students.sae.org/competitions/aerodesign/, visited May 19, 2005. 